\title{
From lung to brain: the pathogenesis of cerebral tuberculosis
}

\section{Guy E Thwaites}

\author{
Address: Centre for Molecular Microbiology and Infection, Imperial College, London SW7 2AZ, UK \\ Email: Guy E Thwaites - guy.thwaites@btinternet.com
}

from Infectious diseases of the nervous system: pathogenesis and worldwide impact

Paris, France. 10-13 September 2008

Published: 23 September 2008

BMC Proceedings 2008, 2(Suppl I):S4I

This abstract is available from: http://www.biomedcentral.com/I753-656I/2/SI/S4I

(c) 2008 Thwaites; licensee BioMed Central Ltd.

Cerebral tuberculosis kills or disables a higher proportion of sufferers than any other form of tuberculosis, yet little is known about the pathogenesis. The seminal studies of Rich and McCordock, performed more than 70 years ago, demonstrated that the development of tuberculous meningitis requires two steps. First, bacteria travel in the blood from the lungs to the meninges where they form discrete foci of infection (Rich foci). Second, foci rupture and release bacteria into the subarachnoid space so heralding the onset of meningitis [1]. Our understanding of the pathogenesis of cerebral tuberculosis has advanced little since these studies.

The primary focus of tuberculous infection is almost always the lung, but how bacteria travel from lung to blood - a critical step in the development of all extra-pulmonary disease - is unknown. M. tuberculosis primarily infects pulmonary alveolar macrophages, which may transport bacteria from the alveolus to the blood. However, the discovery that M. tuberculosis haematogenous dissemination was dependent upon heparin-binding haemagglutinin adhesin, a bacterial virulence factor that interacts with epithelial cells, suggests other trafficking pathways may be important [2]. Animal models of tuberculosis have reported bacteria can be found in the blood soon after pulmonary infection and before the onset of adaptive immunity. Consequently, it is hypothesized that the development of disseminated tuberculosis reflects a failure of the innate immune response to infection. Human studies have shown an association between the development of tuberculous meningitis and polymorphisms in genes encoding Toll-like receptor- 2 and TIRAP (an adaptor protein that mediates signals from Toll-like receptors). Recently, we have shown some strains of $M$. tuberculosis may be more capable of causing disseminated disease than others [3] and there is increasing evidence that different strains elicit different innate immune responses.

Once $M$. tuberculosis reaches the brain the nature of the inflammatory response has long been considered important in determining clinical outcome. A rabbit model of tuberculous meningitis suggested tumour necrosis factor alpha (TNF- $\gamma$ ) was a critical determinant of disease severity and progression [4], which led to trials of thalidomide (a TNF- $\gamma$ antagonist) in humans [5]. Sadly, thalidomide did not benefit children with the disease suggesting a more complex role for TNF- $\gamma$ in human disease. However, controlled trials of adjunctive corticosteroids in children [6] and adults [7] have shown these drugs improve outcome, although this effect has not been clearly linked to decreased intra-cerebral inflammation and the determinants of a protective rather than a destructive immune response remain unclear.

\section{References}

I. Rich AR, McCordock HA: The pathogenesis of tuberculous meningitis. Bull John Hopkins Hosp 1933, 52:5-37.

2. Pethe K, Alonso S, Biet F, Delogu G, Brennan MJ, Locht C, Menozzi FD: The heparin-binding haemagglutinin of $M$. tuberculosis is required for extrapulmonary dissemination. Nature 200I, 412:190-194.

3. Caws M, Thwaites G, Dunstan S, Hawn TR, Lan NT, Thuong NT, Stepniewska K, Huyen MN, Bang ND, Loc TH, et al.: The influence of host and bacterial genotype on the development of disseminated disease with Mycobacterium tuberculosis. PLoS Pathog 2008, 4:el000034.

4. Tsenova L, Bergtold A, Freedman VH, Young RA, Kaplan G: Tumor necrosis factor alpha is a determinant of pathogenesis and 
disease progression in mycobacterial infection in the central nervous system. Proc Natl Acad Sci USA 1999, 96:5657-5662.

5. Schoeman JF, Springer P, van Rensburg AJ, Swanevelder S, Hanekom WA, Haslett PA, Kaplan G: Adjunctive thalidomide therapy for childhood tuberculous meningitis: results of a randomized study. I Child Neurol 2004, 19:250-257.

6. Schoeman JF, Van ZyI LE, Laubscher JA, Donald PR: Effect of corticosteroids on intracranial pressure, computed tomographic findings, and clinical outcome in young children with tuberculous meningitis. Pediatrics 1997, 99:226-231.

7. Thwaites GE, Nguyen DB, Nguyen HD, Hoang TQ, Do TT, Nguyen TC, Nguyen QH, Nguyen TT, Nguyen NH, Nguyen TN, et al.: Dexamethasone for the treatment of tuberculous meningitis in adolescents and adults. N Engl J Med 2004, 35 I: I74I- 1751.

Publish with Bio Med Central and every scientist can read your work free of charge

"BioMed Central will be the most significant development for disseminating the results of biomedical research in our lifetime."

Sir Paul Nurse, Cancer Research UK

Your research papers will be:

- available free of charge to the entire biomedical community

- peer reviewed and published immediately upon acceptance

- cited in PubMed and archived on PubMed Central

- yours - you keep the copyright

Submit your manuscript here:

http://www.biomedcentral.com/info/publishing_adv.asp 